\begin{tabular}{cc}
\hline EJEM & ECONOMIC JOURNAL OF \\
Econ. J. Emerg. Mark. & EMERGING MARKETS \\
Available at http://jurnal.uii.ac.id/index.php/jep \\
\hline
\end{tabular}

\title{
Structural breaks and fiscal sustainability of the Indonesian government budget
}

\author{
Ivantia S. Mokoginta ${ }^{1}$, Ria Marisa Stephanie ${ }^{2}$ \\ ${ }^{1,2}$ Faculty of Economics, Parahiyangan Catholic University, Bandung, Indonesia. \\ e-mail: ivantia@unpar.ac.id
}

\section{Article Info}

Article history:

Received : 5 January 2015

Accepted : 2 March 2015

Published: 1 April 2015

Keywords:

fiscal, debt, portfolio, consolidation, government

JEL Classification: E62, H1, H2, H3

DOI:

http://dx.doi.org/10.20885/ejem .vol7.iss1.art4

\begin{abstract}
The purpose of this study is to identify government policy regimes or structural breaks as indicated by significant changes in debt to GDP ratio and to identify fiscal sustainability in Indonesia from 2000 to 2013. Using Fiscal Reaction Functions framework and Smooth Transition Regression, the study found two structural breaks following the three regimes. Foreign debt repayment dominates the government policy during Regime I. Fiscal consolidations and discipline such as reducing energy subsidies in 2002 and 2005, managing debt portfolio and increasing government revenues were dominant during Regime II. In Regime III, the government increases domestic debt, particularly to finance stimulus package. This study also found that the fiscal is unsustainable during the period of study. Overall, the findings seem to suggest that managing government debt through fiscal consolidations, foreign debt repayment and debt portfolio management is not sufficient to achieve long-term fiscal sustainability.
\end{abstract}

\begin{abstract}
Abstrak
Tujuan penelitian ini adalah mengidentifikasi perubahan struktural pengelolaan anggaran pada saat terjadi perubahan atas rasio utang terhadap PDB dan menguji adanya keberlanjutan fiskal Indonesia selama periode analisis 2000-2013. Dengan menggunakan kerangka Fiscal Reaction Functions dan teknik pengelolaan data Smooth Transition Regression penelitian ini menyimpulkan terjadi dua kali perubahan structural. Selama Regime I, pemerintah berupaya untuk melunasi hutang luar negri, sementara selama Regime II, pemerintah lebih berfokus pada konsolidasi dan disiplin fiskal seperti pengurangan subsidi BBM tahun 2002 dan 2005 , mengelola portofolio utang negara dan meningkatkan sumber penerimaan pemerintah. Selama Regime III, pemerintah berupaya untuk membiayai paket stimulus fiskal melalui penambahan utang dalam negri. Selain itu, penelitian ini menyimpulkan, bahwa keberlanjutan fiskal jangka pendek cenderung rentan,. Temuan ini menujukkan, bahwa strategi fiskal pemerintah yang telah dilaksanakan belum dapat mencapai keberlanjutan fiskal.
\end{abstract}

\section{Introduction}

Recent development of global economic has put Asian countries, including Indonesia, under pressure. This situation is demonstrated by the slowing down of economic growth. Since 2008, the growth of Indonesian economy has been fluctuated. The global economic crisis in 2008-2009 pulled down the growth to only 4.6 percent in 2009 as op- posed to 6.0 percent in 2008. Likewise, the slowing down of economic recovery in Europe and the United States and the economic slows down in both China and India reduced the growth in Indonesia to 6.2 percent in 2012 and 5,8 percent in 2013 (see Figure 1). This situation has put challenged for the Indonesian government to moderate the impact of the distress on domestic economy.

Sources: International Monetary Fund (2010, 2011, 2012); Ministry of Finance (2013). 


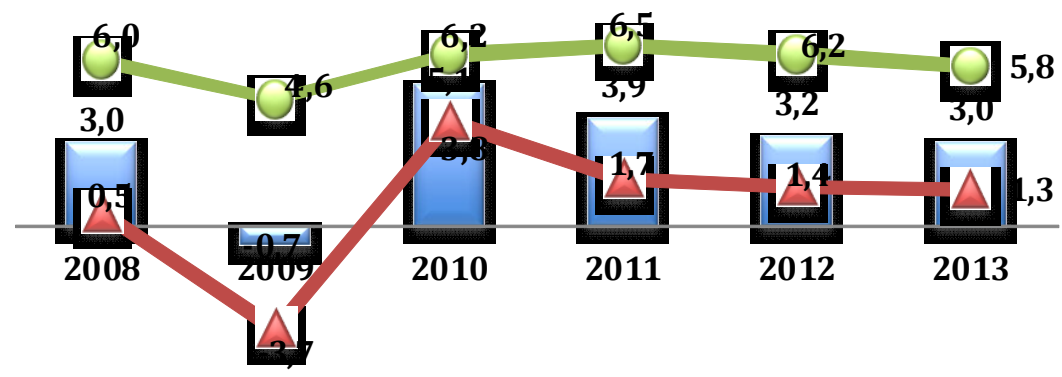

$\varpi$ World $\square \Delta$-Advanced Economic Countries $\quad=0$ - Indonesia

Figure 1: Economic Growth (y.o.y. percent)

As an attempt to moderate the impact, the Indonesian government has committed to introduce fiscal stimulus package that has been implemented since 2009. The aims of the package are: firstly is to maintain purchasing power of households since economic growth is mostly contributed by their consumptions. Secondly is to prevent the increase in unemployment due to the slowing down of domestic business activities. Thirdly is to moderate the impact of lay-offs by creating new jobs related to infrastructure development as businesses streamlining begins. As Figure 1 shows, the package managed to maintain the economic growth at positive level in 2009 and to revive the growth back to 6.2 percent in 2010. However, as domestic economic growth is slowing down (see Figure 1), the government's decisions to spend more on welfare programs can put pressure on fiscal sustainability.

Fiscal sustainability could be achieved as long as the present value of surplus budget is equal to the initial debt and present value of future deficit (Marks, 2004). In other words, fiscal is sustainable if the government can roll over the debt without having to induce hyperinflation or ending in default (Cottarelli \& Escolano, 2014, p. 31). Marks (2004) and Kuncoro (2011) analyze fiscal sustainability of the Indonesian government budget. They used two different approaches and time periods. By using one-primary gap indicator, Marks
(2004) found that the fiscal of the Indonesian government budget from 1990 to 2003 was sustainable except in 1997, 1998 and 2000 when the economy was affected by the Asian financial crisis. He further confirms that exchange rate affected fiscal sustainability during those years. On the contrary, by applying Fiscal Reaction Functions, Kuncoro (2011) found that fiscal sustainability from 1998 to 2009 was vulnerable. He further concludes that domestic debts affect fiscal sustainability.

For the past years, the government of Indonesia has attempted to maintain fiscal sustainability. In 2003, the government issued a law in public finance. Government Regulation no. 23/2003 states that the maximum annual government deficit to GDP ratio must be close to or below 3 percent and government debt to GDP ratio cannot exceed 60 percent. Both ratios are in market prices. A strategy to fulfill the law is by managing the portfolio of total public debts. The purposes of managing the portfolio are to moderate the impact of exchange rates and interest rate on debt repayments and to get alternative sources of fund at more flexible terms.

Fiscal sustainability is also determined by fiscal space or the space in the government budget that can be used for financing discretionary spending. For the past years there has been an indication that the fiscal space of the Indonesian government is limited particularly due to large 
non-discretionary spending. The average annual growth of the spending from 20002012 was 16.75 percent. In 2012, the discretionary spending took about 77 percent of the total government spending. As such, the flexibility of the government to implement discretionary spending was only 23 percent of the total budget or about four percent of the GDP (Nizar, 2013).

As fiscal space is limited, fiscal sustainability of the government might become an issue, especially when there is an economic shock that affects government spending or economic downturn where increasing public debts become inevitable. This situation calls for effective fiscal strategies to manage public debt and hence fiscal sustainability. The strategies might be different depends on the situation on hand. As such, this paper argues that there are three regimes of government fiscal strategies to manage government budget and public debt that had been implemented from 2000 to 2013. The regimes, namely Regime I (prior to February 2000), Regime II (February 2000 to March 2007) and Regime III (after March 2007), correspond with two structural breaks in debt to GDP ratio. Furthermore, this paper also argues that the fiscal of the Indonesian government budget is unsustainable which seems to suggest that the government's fiscal strategies are not sufficient to achieve sustainable fiscal.

To support the argument, the objectives of this study are twofold. Firstly is to identify the two structural breaks in managing government debts particularly when confronted by changing in debt to GDP ratio. Secondly is to identify fiscal sustainability of the Indonesian government budget. To achieve the aim, this study applies Fiscal Response Function (FRF) to follow the path of fiscal responses (Bohn in Lukkezen \& Romagos, 2012; Burger, 2012 and de Mello, 2005). The function is developed based on inter-temporal budget constraint to explain the dynamic of fiscal rule or the extent that the government can maintain fiscal sustainability by identifying the impact of debt changes to surplus primary balance. Fiscal is sustainable if the increase in debt is responded by increasing surplus primary balance. Otherwise, it is unsustainable. There are studies that applied FRF framework to identify fiscal sustainability in various countries. Table 1 below provides summaries of the studies.

De Mello (2005) introduced the role of fiscal institution in the FRF. In his study, the institution is represented by government regulations on budgeting apply to all government levels in Brazil that has been implemented since May 2000. In the model, de Mello (2005) uses dummy variable that affects the intercept of the model. His study found that fiscal institution improves fiscal sustainability in Brazil.

Stoian and Campeanu (2010) conclude that fiscal sustainability is confirmed in Bulgaria, Czech Republic, Estonia, Hungary and Lithuania. In these countries, short term debt shocks are responded by increasing surplus primary balance. They further argue that short-term sustainability lead to long-term sustainability. However, such a behavior is not found in Latvia, Poland, Romania and Slovakia which suggests that fiscal sustainability in these countries might become an issue.

Kuncoro (2011) explains that the solvency of the Indonesian government budget is improving during the period of study. However, his study suggests that even though fiscal sustainability is also improving it remains vulnerable. His finding is based on his hypothesis testing of unsustainable fiscal at $\alpha=10$ percent. He further argues that the vulnerability is due to increasing domestic debts during the period of study. As such, he finally concludes that unless it is managed, domestic debt might disturb fiscal sustainability in the future. 
Table 1: Summaries of Fiscal Sustainability Studies

United States of America: 1970

2008 (Annual data); England:

Smooth Transition

United Stat

1972 - 2008 (Annual data)

Reoression
Unit root \&

Cointegration tests

Least Square \& ANOVA

Spain: 1850 - 1935 \& 1940 - 2010

Portugal: 1852 - 2010; Iceland:

1908 - 2010; United States of

Spain, Portugal, $\quad$ America: 1792 - 2009; England:

Lukkezen \&

Romagosa

2012 Iceland, United States

of America, England,

Netherland, Belgium
1691 - 2009 , Netherland: 1861

1939 \& 1948 - 2009; Belgium

1830 - 1931; 1919 - 1939,

1955 - 2009. Annual data for all

Unit Root Test \&

Fiscal sustainability remains an issue in Spain, Portugal and Iceland. However, this is

Ordinary Least Square not an issue in England, United States of America, Netherlands and Belgium.
This study confirms that fiscal sustainability in Brazil is improving as demonstrated by its ability to maintain primary balance to cover the fluctuations of public debt in the sustainability.

This study found mixed results. Fiscal sustainabilty is confirmed in Bulgaria, Checz Republic, Hungaria and Lithuania. The increase in surplus primary balance to GDP ratio as debt to GDP ratio increases in the short-term supports the findings.

Furthermore, primary balance surplus in the short-term indicates that achieving longterm sustainability in these countries is large. However, in Latvia, Poland, Romania and Slovakia, fiscal sustainability remains an issue.

Fiscal sustainabilty remains vulnerable. Unless it is well managed, high domestic debt relative to foreign debt in the total debt portfolio has the potential for harming the sustainability.

The ratio of debt to GDP is the transition variable in the study. In the United States of America, the study confirms two transition periods, eg. when the ratio is below or above the threshold, $49.4 \%$. Government interventions occurs when the ratio is either above or below the threshold. In England, the study finds three transition periods, eg. when the ratio is low (below 41.3\%), medium (41.3\% - 53.9\%) and high (above $53.9 \%$ ). The government intervenes when the ratio is either low or high. The study also found that fiscal sustainability is confirmed in both countries.

$$
\text { countries }
$$


related to government responses in the two countries. Based on the breaks, he further argues that the government responds differently to different level of debt to GDP ratio. He also concludes that fiscal is sustainable in both countries.

Finally, Lukkezen and Romagos (2012) found that fiscal sustainability is varied among OECD members. In the study, they apply the thresholds of debt to GDP ratio and deficit to GDP ratio of 60 percent and 3 percent, respectively. The thresholds are part of the Maastricht Treaty for European Monetary Union (EMU). By using stochastic simulation technique on public debt, Lukkezen and Romagos (2012) identify the probability that the countries under study increase their debt to GDP ratio by 20 percent above the threshold. Those countries with high probability indicate unsustainable fiscal.

Based on the prior studies above, this study uses Smooth Transition Regression (STR) method developed by Terasvirta (2004) to achieve the second aim of this study. The method allows estimation of a non-linear equation model to identify structural breaks or changes in economic regime. The breaks or changes represent government reactions in the form of budget strategies to the changes in debt to GDP ratio.

This study also looks at the dynamic analysis of fiscal sustainability to identify the changes in government's fiscal strategies, particularly when the time of changes is unknown. To achieve the aims, this study uses monthly time series data from 2000 to 2013. Except for inflation, exchange rate and interest rate, the rest of the data are interpolated from annual data published by the Statistic Office, Bank Indonesia and Ministry of Finance.

\section{Research Method}

The dynamic of government budget: fiscal reaction function
Fiscal Reaction Functions (FRF) is a behavioral function of government budget when confronted by a change on debt. The behavior is usually measured by the reaction of primary balance to GDP ratio as the debt to GDP ratio changes. The behavioral function is developed based on the government's inter-temporal budget constraint and identity. As such, understanding the structure of government budget is critical.

In general, the government budget comprises of tax revenues $(T)$ and expenditures $(G)$. Based on the structure, the position of revenues and expenditures determine the posture of government budget, namely balance budget if $T=G$, budget deficit if $T<G$ and budget surplus if $T>$ $G$. In a situation when the posture is in deficit, the government needs to look for alternative financing, such as public debt $(D)$.

When government decides to finance budget deficit with public debt, fiscal sustainability might become an issue. The issue emerges since public debt exposes the budget to interest rate risk $(r)$. However, when the debt is utilized to finance productive activities such as investment in infrastructures, the debt will generate income, and hence economic growth $(g)$. As such, the inter-temporal effects of public debt on economic performance determine fiscal sustainability and, hence, the government budget constraint.

Based on the argument above, intertemporal budget constraint to finance the deficit is $\mathrm{Dt}=-\mathrm{Bt}$, where $B_{t}=T_{t}-G_{t}$. When $\Delta D_{t}=D_{t}-D_{t-1}$, the constraint after accounting for interest payment $\left(r D_{t-1}\right)$ and economic growth $\left(g D_{t-1}\right)$ is stated in Equation (1) below (Burger, 2012; de Mello, 2005):

$$
D_{t}=D_{t-1}+\left(r_{t}-g_{t}\right) D_{t-1}-B_{t}
$$

or

$$
\Delta D_{t}=\left(r_{t}-g_{t}\right) D_{t-1}-B_{t}
$$

where $D=$ public debt, $r=$ real interest rate on government bonds, $g=$ economic growth and $B=$ primary balance. The equa- 
tion assumes that government does not implement monetary financing or seigniorage for deficit financing or $\Delta m_{t}=0$.

Divided Equation (1) by $Y$ or nominal GDP gives Equation (2) below:

$$
\begin{aligned}
& \Delta(D / Y)_{t}=\left(r_{t}-g_{t}\right)\left(\frac{1}{1+g_{t}}\right)(D / Y)_{t-1}-(B / Y)_{t} \text { or } \\
& \Delta d_{t}=\left(r_{t}-g_{t}\right)\left(\frac{1}{1+g_{t}}\right) d_{t-1}-b_{t}
\end{aligned}
$$

Assuming debt to GDP ratio remains unchanged i.e. $\Delta d_{t}=$ Ogives Equation (3):

$$
b_{t}=\left(r_{t}-g_{t}\right)\left(\frac{1}{1+g_{t}}\right) d_{t-1}
$$

Equation (3) suggests that if the debt to GDP ratio is held constant $(\bar{d})$, then the government will apply this following fiscal rule:

$$
b_{t}^{\text {Re } q u i r e d}=\alpha_{t}{ }^{*} d_{t-1}=\left(r_{t}-g_{t}\right)\left(\frac{1}{1+g_{t}}\right) \bar{d}_{t-1}
$$

where $\alpha_{t}^{*}$ is the fiscal rule or the required fiscal reaction function (Burger, 2012, p. 936). The rule suggests a fraction of the debt at previous year that can be covered by required primary balance. As such, high $\alpha_{t}^{*}$ corresponds with high fiscal sustainability.

The dynamic of government behavior is represented by the lag of primary balance $b_{t-1}$ (Burger, 2012 and de Mello, 2005).

The actual fiscal behavior is an estimated fiscal reaction function written as follows:

$$
\begin{aligned}
b_{t}^{\text {Actual }} & =\alpha_{0}+\alpha_{1} d_{t-1}+\alpha_{2} \mathrm{~b}_{\mathrm{t}-1} \text { Actual } \\
& +\beta_{\mathrm{k}} \sum_{k=1} X_{k t}+\varepsilon_{t}
\end{aligned}
$$

where Xs are other explanatory variables in the fiscal reaction functions.

In this study, $\mathrm{Xs}$ in Equation (5) represent macroeconomic assumption variables which comprises of economic growth, inflation, Indonesia Crude-oil Price, interest rate and exchange rate of IDR per USD. These variables are used by the government to prepare annual government budget. As such, it represents the extent that the government acknowledges and manages fiscal risks based on the changes in the assumptions. By so doing, this study could reveal the extent of government's efforts to maintain fiscal sustainability due to changes in macroeconomic factors.

\section{Data and data processing technique}

This study uses data collected from the Statistic Office, Central Bank of Indonesia and Ministry of Finance. The period of analysis is $2000-2013$. The monthly data are obtained by using interpolation technique from annual data. Table 2 below presents the indicators for variables in Equation (5).

This study used Smooth Transition Regression (STR) technique since it allows non-linear modeling to capture structural breaks or changes in economic regime. The estimation of non-linear modeling is particularly important to take into account the changes in economic regime during the period of analysis. In this study, the regimes are government responses or policies to changes in debt. Equation (6) below represents a matrix form of generalized smooth changes between economic regimes using STR model:

$$
\begin{aligned}
y_{t} & =\varphi^{\prime} z_{t}+\theta^{\prime} z_{t} G\left(\gamma, c, s_{t}\right)+u_{t} \\
& =\left\{\varphi+\theta G\left(\gamma, c, s_{t}\right)\right\}^{\prime} z_{t}+u_{t}, \\
t & =1, \ldots, T
\end{aligned}
$$

where $z_{t}=\left(w_{t}^{\prime}, x_{t}^{\prime}\right)$ are explanatory variables, $\quad w_{t}^{\prime}=\left(1, y_{t-1}, \ldots, y_{t-p}\right)^{\prime} \quad$ and $x_{t}^{\prime}=\left(x_{1 t}, \cdots, x_{k t}\right)^{\prime}$. In this study, the Xs are the variables of macroeconomic assumption. The error term meets the $u_{t} \sim \operatorname{iid}\left(0, \sigma^{2}\right)$ property. 
Table 2: Operational Variables in the Model

\section{Dependent Variable}

\begin{tabular}{|c|c|c|c|}
\hline & \multicolumn{2}{|c|}{ Ratio of cyclically adjusted primary balance to GDP* } & $\begin{array}{c}\text { Source } \\
\text { Ministry of Finance }\end{array}$ \\
\hline \multicolumn{4}{|c|}{ Explanatory Variables } \\
\hline & \multicolumn{2}{|c|}{ I. Components of Macroeconomic Assumptions } & Sources \\
\hline 1 & Economic growth & GDP growth & Statistic Office \\
\hline 2 & Inflation rate & CPI & Statistic Office \\
\hline 3 & Real interest rate & $\begin{array}{l}\text { Certificate of Bank Indonesia and BI } \\
\text { rate }\end{array}$ & Bank Indonesia \\
\hline 4 & Indonesia's Crude Oil Price & USD per barrel & $\begin{array}{l}\text { Ministry of Energy } \\
\text { and Mineral } \\
\text { Resources }\end{array}$ \\
\hline 5 & Exchange rate & IDR per USD & Bank Indonesia \\
\hline \multicolumn{3}{|c|}{ II. Other Explanatory Variable } & Sources \\
\hline & Ratio of debt to GDP & & Ministry of Finance \\
\hline
\end{tabular}

Note: *cyclically adjusted primary balance to GDP ratio is used to eliminate the impact of automatic stabilizer on primary balance due to business cycle.

\section{Transitional function LSTR1}

at $\mathbf{C}=\mathbf{1}$

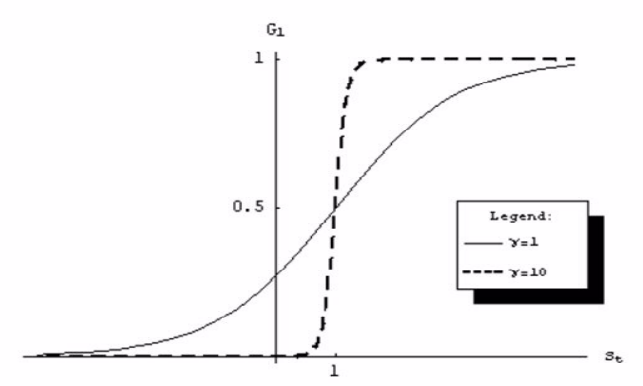

Transitional function LSTR2 at $\mathrm{C}_{1}=\mathbf{- 1}$ and $\mathbf{C}_{2}=1$

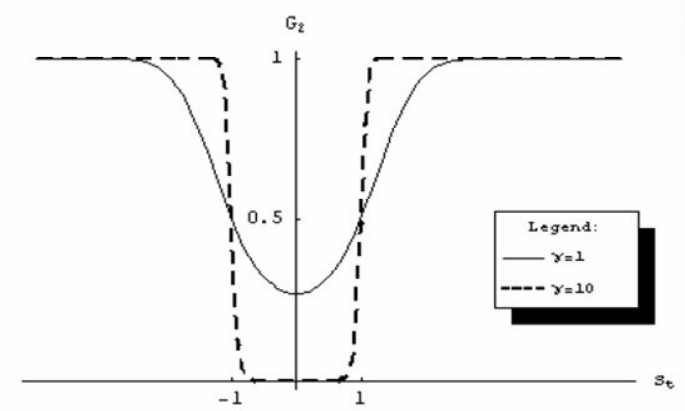

Source: Kavkler, et al (n.d, pp. 6-7)

Figure 2: Transitional Functions

STR technique produces both linear and non-linear estimation results. The first segment of Equation (6) represents the linear function with $\varphi$ as its parameters' matrix whereas the second segment is the nonlinear function with $\theta$ as its parameters' matrix. The function $\mathrm{G}(\gamma, c, s t)$ in the nonlinear segment is a continuous transition function bounded between 0 and 1 . The function represents both the extremes (eg. 0 or 1) and gradual (eg. between 0 and 1) changes of economic regime. The slope parameter is $\gamma>0$, c shows where the tran- sition takes place and st is the transition variable that is usually the time trend or one of the explanatory variables.

The general form of the transition function or known as Log STR (LSTR), is shown as follows (Terasvirta, 2004, p. 223):

$$
G\left(\gamma, c, s_{t}\right)=\left(1+\exp \left\{-\gamma \prod_{k=1}^{K}\left(s_{t}-c_{k}\right)\right\}\right)^{-1}
$$

where $\gamma>0$ is an identifying restriction and parameters $\varphi+\theta \mathrm{G}(\gamma, c, s t)$ changes mono- 
tonically with respect to st. The usual form of the function is either $K=1$ or $K=2$. When $\mathrm{K}=1$, st. will change monotonically from $\varphi$ to $\varphi+\theta$. However, when $\mathrm{K}=2$, st. will change symmetrically around $1 / 2\left(\mathrm{c}_{1}+\right.$ $\mathrm{c}_{2}$ ) and the function $(\mathrm{G})$ reaches its minimum value. LSTR $=0$ when $\gamma \rightarrow \sim$ and equals $1 / 2$ when $\mathrm{c}_{1}=\mathrm{c}_{2}$ and $\gamma<0$.

Equations (6) and (7) jointly defined the LSTR model, namely whether the function is LSTR1 or LSTR2 as shown in Figure 2. Parameter $\gamma$ in Figure 2 indicates the transition speed of the transition variable. The larger the value of $\gamma$ the faster the speed of transition.

STR technique follows a modeling cycle consisting of three stages, namely specification, estimation and evaluation stages. In the specification stage, a linearity test should be carried out by using auxiliary regression as follows (Terasvirta, 2004, pp. 226-227):

$y_{t}=\beta_{0}^{\prime} z_{t}+\sum_{j=1}^{3} \beta_{j}^{\prime} \tilde{z}_{t} s_{t}^{j}+u_{t}^{*}, \quad t=1, \cdots, T$

where $u_{t}^{*}=u_{t}+R_{3}\left(\gamma, c, s_{t}\right) \theta^{\prime} z_{t}$ with the remainder $R_{3}\left(\gamma, c, s_{t}\right)$.

The linear hypothesis testing of the model is $H_{0}: \beta_{1}=\beta_{2}=\beta_{3}=0$ because each $\beta_{j}, j=1,2,3$ is of the form $\gamma \tilde{\beta}_{j}$ where $\tilde{\beta}_{j} \neq 0$ is a function of $\theta$ and $c$.

After linearity has been rejected, the next step is to select a model, eg. LSTR1 or LSTR2, which corresponds with $\mathrm{K}=1$ or $\mathrm{K}$ $=2$, respectively. In the special case where $\mathrm{c}=0$ and $\beta 2=0$, the model is an LSTR1 model or there are one structural break (two regimes). When $c=0$ and $\beta 1=\beta 3=0$, the model is an LSTR2 model or there are two structural breaks (three regimes). In cases where $c \neq 0, \beta 2$ is closer to the null vector than $\beta 1$ and $\beta 3$ in two regimes and vice versa in three regimes (Terasvirta, 2004, p. 227 and Burger, 2012, p. 939). Based on the above arguments, the null hypotheses testing for selecting a model using Equation $(8)$ are:

$$
\begin{aligned}
& H_{04}: \beta_{3}=0 \\
& H_{03}: \beta_{2}=0 \mid \beta_{3}=0 \\
& H_{02}: \beta_{1}=0 \mid \beta_{2}=\beta_{3}=0
\end{aligned}
$$

All of these hypotheses can be rejected at different $\alpha$ levels. However, if $\mathrm{H}_{03}$ suggests the strongest rejection based on the smallest p-value of the hypotheses testing, then selects LSTR2 model. Otherwise, selects LSTR1 model.

The next stage is to estimate the parameters of the STR model represented by Equation (6) using conditional maximum log-likelihood. The last stage is to ensure that the estimated LSTR model is not missspecified by testing for no-autocorrelation. This study uses data processing JMulti program for time series analysis which is available online (Kratzig, 2005).

\section{Result and Discussion}

Before estimating the model, this study applies stationary test for the data. The stationary test shows that at $\alpha=5$ percent, debt to GDP ratio, inflation and economic growth are stationary at level whereas exchange rate is stationary at level at $\alpha=10$ percent. The rest of the data, namely cyclically adjusted primary balance to GDP ratio, Indonesia crude oil price and real interest rate are stationary at first difference. Based on the test, this study transforms cyclically adjusted primary balance to GDP ratio, Indonesia crude oil price, real interest rate and exchange rate into first difference and maintains debt to GDP ratio, inflation and economic growth at level.

Furthermore, the study introduces two dummies into the model to represent shocks in the Indonesia Crude-oil Price (eg. ICP $\geq$ USD100 per barrel) and IDR depreciations (eg. IDR per USD $\geq 10,000$ ). In the dummies, the shocks are represented by 1 and the rest are zero. As such, the data processing can capture the shocks and ana- 
lyze the impact of the shocks on the cyclically adjusted primary balance to GDP ratio. In additions, this study uses debt to GDP ratio as the transition variable (set up a priory) so that the analysis can focus on identifying the impact of changes in debt to GDP ratio to cyclically adjusted primary balance to GDP ratio.

Based on the above transition variable, the study found that LSTR2 functional model is the best one to estimate Equation (6). Attachment A shows the complete F test results for selecting the best model. The model is selected based on the p-value of $\mathrm{F}$ for non-linearity test. The rejection of linearity test $(\mathrm{F})$ confirms that the transition variable, namely the debt to GDP ratio, is a non-linear function. The rejection is based on $\alpha=2.5335 \mathrm{e}-48$ percent. Furthermore, the smallest $p$-value of $F$ tests which is F3 for $\mathrm{H}_{03}$ hypothesis testing rejects LSTR1 at $\alpha=6.8938 \mathrm{e}-21$. As such, this study uses LSTR2 model. The model implies two structural breaks in debt to GDP ratio or three regimes of intervention in managing fiscal sustainability. The regimes represent different government fiscal strategies in Regime I, Regime II and Regime III.

In processing the data, restriction on debt to GDP ratio is set up at $\theta=-\varphi$, i.e. the ratio equals to zero when $G=1$, to explore measures in Regime II other than intervening directly with the size of debt, hence, the debt to GDP ratio. These measures can include fiscal consolidations and fiscal disciplines. Table 3 below presents the estimation results.

Table 3: Estimation Results

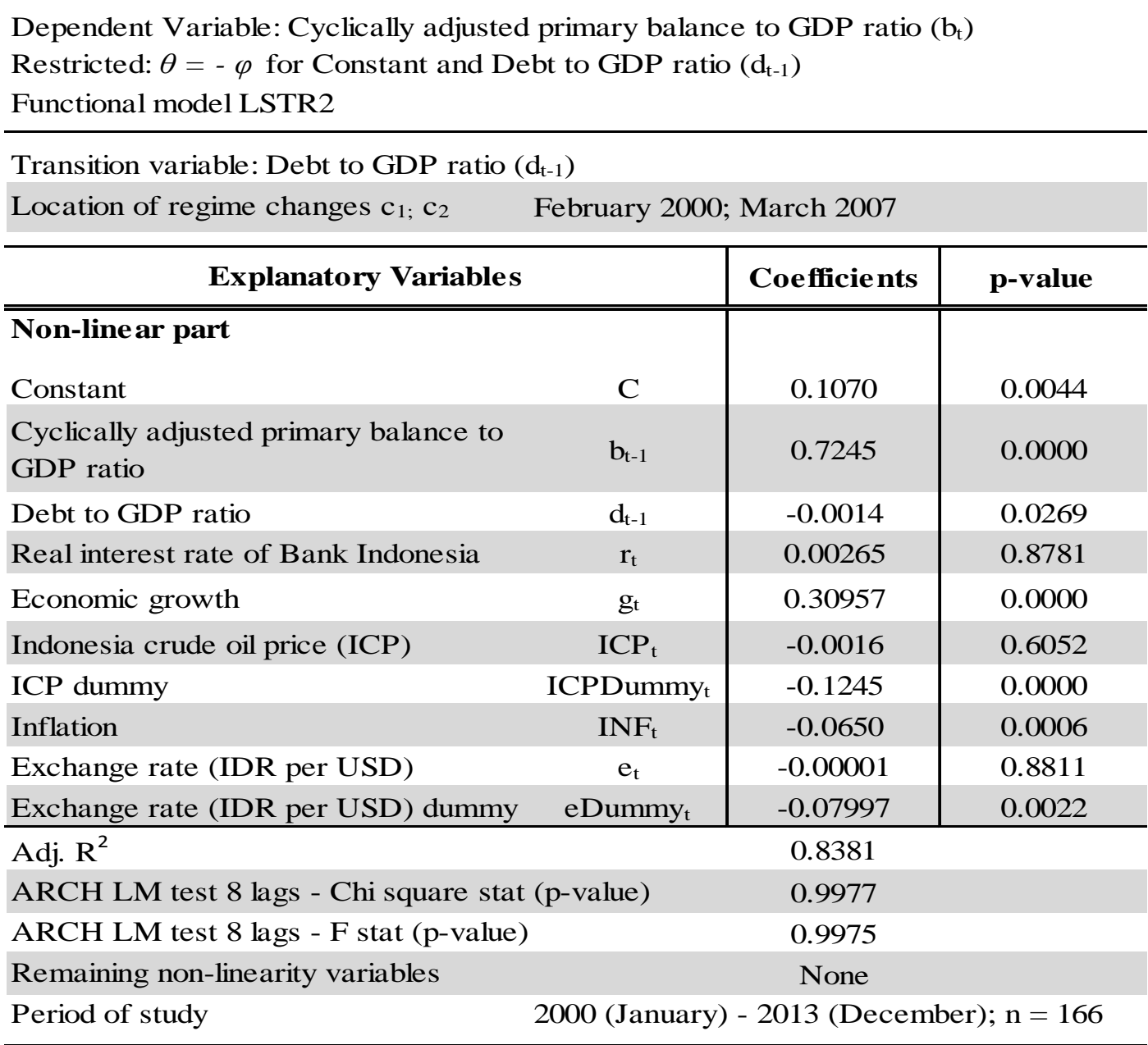

Souces: Attachments A - C 
The data processing found that there are two structural breaks based on debt to GDP ratio at two different times, namely 95.21 percent in February of 2000 and 36.03 percent in March of 2007. Based on the two breaks, there are three fiscal policy regimes, namely Regime I (prior to February 2000), Regime II (between February 2000 and March 2007) and Regime III (after March 2000). As will be explained below, the government uses different interventions or fiscal strategies to maintain fiscal sustainability in each regime.

During Regime I, reducing foreign debts during recovery from Asia Financial crisis of 1997/1998 become inevitable. From January 2000 to February 2000, the declining rate of debt to GDP ratio was 1.62 percent (Calculated from Bank Indonesia, 2013). Since at the same period the GDP growth was declining by 1.3 percent, it can be inferred that the declin ing ratio was mostly due to declining debt.

Regime II focuses on fiscal consolidations. The consolidations include: Firstly is reducing energy subsidies in 2002 and in 2005. The impact of the policy is that primary balance was increasing by 137.2 percent in 2002 and 131.3 percent in 2005 (Calculated from Bank Indonesia, 2013).
As such, it could be asserted that reducing energy subsidies improve surplus primary balance and, hence, fiscal sustainability in the short run.

Secondly is managing debt portfolio. Since debt affects fiscal sustainability, the Indonesian government has decided to manage the debts. As previously explained, since 2003, the government has been implemented the thresholds of debt to GDP ratio and deficit to GDP ratio of 60 percent and -3 percent, respectively. The strategy of implementation is, among others, by managing the portfolio of total public debt. Since then, the percentage of foreign debts to total debt has been declining whereas the percentage of domestic debt increasing. By 2013, domestic debt held about 72.4 percent of the total debt (see Figure 3).

Thirdly is increasing government revenues from taxes and non-taxes. The Indonesian government has also issued several tax laws and regulations related to income tax, value added taxes, tax on luxurious goods, custom tax and excises (Ministry of Finance, 2006, p. IV-62). These laws and regulations were ratified in 2007 and have been fully implemented since 2008.

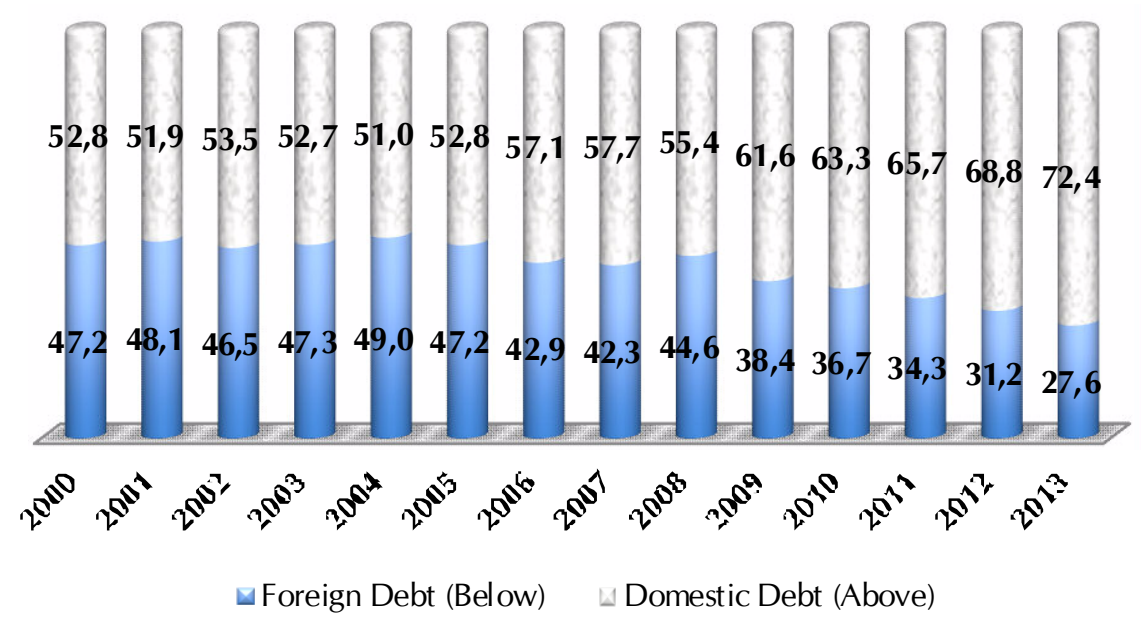

Sources: Ministry of Finance (2004, 2005, 2013 \& 2014)

Figure 3: Portfolio of Foreign and Domestic Debts to Total Public Debts (in percentage) 
Finally, during Regime III, the government attempts to increase fiscal space by increasing mostly domestic public debt, particularly when the government had to finance fiscal stimulus package to overcome the 2008 global economic crisis. This strategy seems to contribute to public debt portfolio management as demonstrated by a significant decline in foreign debt as opposed to domestic debt.

Table 3 (non-linear part) shows that real interest rate, ICP and exchange rate are not significantly different from zero at $\alpha=$ 5 percent and 10 percent. As such, these variables do not have significant impact on the cyclically adjusted primary balance to GDP ratio. However, the dummies of oil price and exchange rate do. The negative signs of the shocks' coefficients mean that as the oil price increases and IDR depreciates the surplus primary balance to GDP ratio declines. The impact of the shocks on fiscal sustainability is significantly correlated with subsidies provided by the government. These subsidies include those on energy which comprises 80 percent of total subsidies (Ministry of Finance, 2014). Since Indonesia is an oil importer country, shocks on oil price and currency depreciations affect government expenditures and, hence, surplus on primary balance and fiscal sustainability.

Furthermore, there is an inverse relationship between inflation and the primary balance to GDP ratio. It seems to suggest that the increase in inflation is responded by declining surplus primary balance to GDP ratio. This finding confirms the importance of monetary and fiscal policies coordination to manage inflation to ensure fiscal sustainability. In addition the positive effect of economic growth on surplus primary balance to GDP ratio suggests counter-cyclical effect. When economic growth increases, the surplus primary balance to GDP ratio will follow suit. This fact seems to suggest a catch-up GDP growth to obtain fiscal sustainability. However, the growth is not sufficient to achieve fiscal sustainability during the period of study. As such, this study seems to confirm previous study that fiscal sustainability of Indonesia remains vulnerable (Kuncoro, 2011)

\section{Conclusion}

This study found three periods of policy regimes based on debt to GDP ratio, namely Regime I, Regime II and Regime III. In the study Regime I occurred prior February 2000, Regime II took place between February 2000 and March 2007 and Regime III happened after March 2007. In each regime, the government responded differently to different level of debt to GDP ratio. During Regime I, repaying foreign public debt is the priority, whereas during Regime II, fiscal consolidations and disciplines such as reducing energy subsidies, managing public debt portfolio and increasing government revenues are important. During Regime III, the government increases domestic public debt to finance stimulus package.

This study also concludes that the fiscal is unsustainable during the period of study. The negative impact of increasing debt to GDP ratio on surplus primary balance to GDP ratio supports the finding. The counter-cyclicality impact of economic growth on surplus primary balance to GDP ratio is not sufficient to improve fiscal sustainability since the trend of the ratio is declining. In addition, the deficit primary balance to GDP ratio since 2012 also supports the finding.

Overall, the findings seem to suggest that managing government debt through fiscal consolidations, foreign debt repayment and debt portfolio management that have been implemented during the period of study is not sufficient to achieve long-term fiscal sustainability. Finally, the counter-cyclical impact of economic growth on surplus primary balance to GDP ratio seem to suggest a fundamental improvement in the real sector that ensures sustainable growth and, hence, sustainable 
fiscal. However, these issues are beyond the scope of this study.

\section{References}

BIBLIOGRAPHY 3081 Bank Indonesia, (2013),"Sektor Keuangan Pemerintah,"

http://www.bi.go.id/id/statistik/seki/ terkini/keuangan-

pemerintah/Contents/Default.aspx,

accessed 15 Juni 2014, 13.30 west Indonesian time.

BIBLIOGRAPHY \I 3081 Burger, P., (2012),"Fiscal Sustainability and Fiscal Reaction Functions in the US and UK,". International Business \& Economics Research Journal, 11(8), 935-942.

Cottarelli, C. and J. Escolano, (2014),"Debt Dynamics and Fiscal Sustainability," in: Cottarelli, C., Gerson, P. and Senhadji, A. (eds), Post-crisis Fiscal Policy. London: MIT Press, 31-47.

de Mello, L., (2005),"Estimating a Fiscal Reaction Function: the Case of Debt Sustainability in Brazil," http://eurlex.europa.eu/en/treaties/dat/11992 M/htm/11992M.html\#0084000006, accessed on 14 February 2014, 12.30 west Indonesian time.

International Monetary Fund, (2010),"World Economic Outlook: Rebalancing Growth," Washington, D.C.: IMF.

International Monetary Fund, (2011),"World Economic Outlook: Slowing Growth, Rising Risks," Washington, D.C.: IMF.

International Monetary Fund, (2012),"World Economic Outlook: Coping with High Debt and Sluggish Growth," Washington, D.C.: IMF.
Kavkler, A., et al, (n.d),"Nonlinear Econometric Models: the Smooth Transition Regression Approach," http://www.iweb.cerge-

ei.cz/pdf/gdn/RRCVI_36_paper_01. pdf, accessed 25 March 2014, 13.30 west Indonesian time.

Kratzig, M. (2005),"STR Analysis in JMulTi," http://www.jmulti.de, accessed 1 March 2014, 10.25 west Indonesia time.

Kuncoro, H., (2011),"The Sustainable of State Budget in Debt Repayment," Bulletin of Monetary, Economics and Banking, April, 415 - 434.

Lukkezen, J. and H.R. Romagos, (2012),"When is Debt Sustainable?," CPB Discussion Paper 212 ed. The Hague: CPB Netherlands Bureau for Economic Policy Analysis.

Marks, S. V., (2004),"Fiscal Sustainability and Solvency: Theory and Recent Experience in Indonesia," Bulletin of Indonesian Economic Studies, 20(2), 227-242.

Ministry of Finance, (2003),"State Budget of Fiscal Year 2004," Jakarta: Directorate General of Budget.

Ministry of Finance, (2004),"State Budget of Fiscal Year 2005," Jakarta: Directorate General of Budget.

Ministry of Finance, (2006),"State Budget of Fiscal Year 2007," Jakarta: Directorate General of Budget

Ministry of Finance, (2012),"State Budget of Fiscal Year 2013,". Jakarta: Directorate General of Budget.

Ministry of Finance, (2013),"Proposal of State Budget for Fiscal Year 2014,". Jakarta: Directorate General of Budget.

Ministry of Finance, (2014),"Proposal of State Budget for Fiscal Year 2015", 
Jakarta: Directorat General of Budget.

Nizar, M. A., (2013),"Rigiditas Fiskal: Masih Adakah Peluang Fleksibilitas Pemerintah?," Warta Fiskal, Issue 1, 5-6.

Stoian, A. and E. Campeanu, (2010),"Fiscal Policy Reaction in the Short-term for Assessing Fiscal Sustainability in the Long run in Central and East- ern Europe Countries," Czech Journal of Economics and Finance, 60(6), 501-518.

Terasvirta, T., (2004),"Smooth Transition Regression Modeling," in: Lutkepohl, H. and Kratzig, M. (eds), Applied Time Series Econometrics, 222-242, Cambridge: Cambridge University Press. 


\section{Attachment A - Non-linearity Test \\ *** Sat, 29 Nov 2014 21:41:10 *** \\ TESTING LINEARITY AGAINST STR}

variables in AR part: CONST CAPrim_d1(t-1) Bunga_riil_d1(t) Growth(t) Inflasi(t) Utang_lag(t) ICP_d1(t) Kurs_d1(t) param. not under test:

sample range: [2000 M3, $2013 \mathrm{M} 12], \mathrm{T}=166$

p-values of F-tests ( $\mathrm{NaN}$ - matrix inversion problem):

$\begin{array}{llllll}\text { transition variable } & \mathrm{F} & \mathrm{F} 4 & \mathrm{~F} 3 & \mathrm{~F} 2 & \text { suggested model }\end{array}$

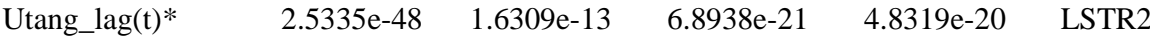

\section{Attachment B - Estimation Results}

*** Sat, 29 Nov 2014 19:29:38***

STR ESTIMATION

variables in AR part: CONST CAPrim_d1(t-1) Bunga_riil_d1(t) Growth(t) Inflasi(t) Utang_lag(t) ICP_d1(t) Kurs_d1(t) restriction theta $=0$ :

restriction phi $=0$ : KursdumM2 ICPdumM2

restriction phi=-theta: CONST Utang_lag(t)

transition variable: $U$ tang $\operatorname{lag}(\mathrm{t})$

sample range: [2000 M3, $2013 \mathrm{M} 12], \mathrm{T}=166$

transition function: LSTR2

number of iterations: 21




ATTACHMENT C - Model Specification Test

*** Sat, 29 Nov 2014 21:44:29***

Test of No Remaining Nonlinearity ( $\mathrm{NaN}$ - matrix inversion problem):

$\begin{array}{lrrrr}\text { transition variable } & \text { F } & \text { F4 } & \text { F3 } & \text { F2 } \\ \text { CAPrim_d1(t-1) } & 2.3888 \mathrm{e}-12 & 1.0055 \mathrm{e}-04 & 1.4736 \mathrm{e}-02 & 2.9897 \mathrm{e}-10 \\ \text { Bunga_riil_d1(t) } & 3.6862 \mathrm{e}-01 & 2.1916 \mathrm{e}-01 & 9.2535 \mathrm{e}-01 & 8.4688 \mathrm{e}-02 \\ \text { Growth(t) } & 2.6262 \mathrm{e}-09 & 8.0814 \mathrm{e}-09 & 1.8378 \mathrm{e}-02 & 3.0055 \mathrm{e}-02 \\ \text { Inflasi(t) } & 3.4507 \mathrm{e}-04 & 1.2583 \mathrm{e}-01 & 1.5566 \mathrm{e}-03 & 1.0153 \mathrm{e}-02 \\ \text { ICP_d1(t) } & 5.7068 \mathrm{e}-03 & 6.1262 \mathrm{e}-03 & 7.3920 \mathrm{e}-01 & 7.7581 \mathrm{e}-03 \\ \text { Kurs_d1(t) } & 2.0404 \mathrm{e}-01 & 9.5456 \mathrm{e}-02 & 9.0079 \mathrm{e}-01 & 7.0976 \mathrm{e}-02\end{array}$

*** Sat, 29 Nov 2014 21:44:29 ***

Parameter Constancy Test (NaN - matrix inversion problem):

variables not under test:

$\begin{array}{lrrrr}\text { transition function } & \text { F-value } & \text { df1 } & \text { df2 } & \text { p- value } \\ \text { H1 } & 25.8175 & 18.0000 & 126.0000 & 0.0000 \\ \text { H2 } & 15.1814 & 36.0000 & 108.0000 & 0.0000 \\ \text { H3 } & 13.0942 & 54.0000 & 90.0000 & 0.0000\end{array}$

ARCH-LM TEST with 8 lags for "str_resids"

\begin{tabular}{lrr} 
test statistic & $:$ & 1.0831 \\
p-Value(Chi^2) & $:$ & 0.9977 \\
F statistic & $:$ & 0.1363 \\
p-Value(F) & $:$ & 0.9975 \\
JARQUE-BERA & TEST for "str_res \\
\multicolumn{3}{l}{} \\
test statistic & $:$ & 1969.3343 \\
p-Value(Chi^2) & $:$ & 0.0000 \\
skewness & $:$ & 3.5157 \\
kurtosis & $:$ & 18.3389
\end{tabular}

